\title{
The Effect of Internet Channels on the Market Value: AR and EVA Perspectives
}

\author{
Hung-Jen Tu \\ Providence University \\ E-Mail: hill@ms41.url.com.tw \\ Jia-Jeng Hou \\ National Chiayi University \\ E-Mail: jjhou@mail.ncyu.edu.tw
}

\begin{abstract}
The emergence of the Internet has forced a wealth of firms to explore a new form of channels of distribution, i.e., Internet channels. Nevertheless, empirical studies evaluating the values to firms from the adoption of Internet channels are limited. In order to fill in the literature gap, an empirical study to assess the effect of Internet channels on the market value was conducted in Taiwan. By applying event study methodology, accompanied with Economic Value Added, the research examined firms' market values after adding Internet channels. The results showed that the magnitudes of the CAARs were uniformly positive and significant in $[-10,+10]$ windows; the relationship between EVA before/after introducing Internet channels and abnormal returns were positive; EVA after adding Internet channels dominated EVA before adding Internet channels in explaining abnormal returns. In conclusion, the research has provided insights into the performance implications of Internet channels for firms.
\end{abstract}

Keywords: Internet Channels, Market Value, Economic Value Added, Abnormal Return. 


\section{INTRODUCTION}

Multiple channels are becoming the most common distribution strategy in the current increasingly competitive business environment (Zettelmeyer, 2000). The emergence of the Internet has forced a large number of firms, both in B2B and B2C environments, to explore Internet-based distribution channels, i.e., Internet channels, to market their products. However, adding such an Internet channel system into their existing channel systems will confront with opportunities as well as threats (Geyskens, Gielens, \& Dekimpe, 2002). Therefore, the use of Internet channels strategy could undermine the firms' performance and further jeopardize their operation as well.

Despite the uncertainty surrounding the performance implications of Internet channel additions strategy, countless firms have still rushed to build Internet channels to access potential millions of online customers directly. We are looking forward to investigating the managerial performance of Internet channels for firms through the research. This study employs economic value added (EVA hereafter) and abnormal return (AR hereafter), stemming from event study methodology, to assess the effect of Internet channels on the market value. Empirical research regarding to the announcement of Internet channels issues has not been conducted for the Taiwan case where particularly the stock market has experienced a notable development thanks to the economic growth exhibited in the last 20 years. In spite of some Taiwan companies currently using performance measures like EVA, there are few studies that try to link these measures to the Taiwan shareholders' wealth changes after adding Internet channels.

This research differs from those that have been reported in the past literature in at least two aspects. First, most of the previous studies are concentrated on the U.S. case. This study recognizes that there exist developing business environments (i.e., Taiwan) that are possible to be analyzed. Second, although firms use EVA indicator for measuring managerial performance, virtually there are few researches reported in literature that provide information about the statistical relationship of EVA and AR regarding Internet channels. In the following sections, related literature including performance evaluation of Internet channels, event study, and EVA will be depicted. Hypotheses development and research methodology will then be reported, followed by results. Research conclusion will be in the final section. 


\section{LITERATURE REVIEW}

\section{Performance Evaluation of Internet Channels}

The concept of marketing channel performance has been the subject of considerable scholarly research over the past decade (Sharma, Sahay, \& Sachan, 2004), but efforts to develop valid empirical measures have been quite limited (Spriggs, 1994). Among the studies that include performance often emphasize the observable indicators such as sales, interfirm power, retail productivity, return on assets and investments, asset turnover, payoff ratios, profits, market share, and economic as well as social satisfaction (for example, Frazier, Gill, \& Kale, 1989; Geyskens \& Steenkamp, 2000; Katsikeas, Paparoidamis, \& Katsikea, 2004; Ramaseshan, Yip, \& Pae, 2006). They have all been used either separately or in ad hoc combinations as criteria to evaluate the marketing channel performance. However, many of these studies claim their measures are indicators of marketing channel performance, but fail to legitimize those claims with a clear definition of the domain being measured or provide evidence of validity (Spriggs, 1994). Generally speaking, the theoretical rationale to support the selected criteria of marketing channel performance is often limiting or weak in marketing channel context (Kumar, Stern, \& Achrol, 1992).

Due to intensified market competition and the development of the Information Technology (IT), especially Internet technology, the channel system context is changing (Stewart \& Zhao, 2000). The Internet-based electronic distribution channel is perhaps the most important duct for direct consumer interaction with firms as it offers the potential not only for increasing the frequency and quality of value chain communication, and reducing cost but also for new marketing opportunities (Aitchison \& Stone, 2002). The Internet as an addition to the physical channel system has become critical, and a large number of firms have increasingly utilized such a dual channel system to market their products (Reda, 1999). It is believed that the adoption of the Internet as channel addition can achieve high level of customer lifetime value (CLV) (Rajkumar \& Kumar, 2004), and enhance a firm's competitive advantages (Reda, 1999). With the Internet channel maturing and stabling, numerous firms face a challenge of how to evaluate the performance of the Internet channels (King \& Liou, 2004). The evaluation of Internet channels has become increasing important for fine-tuning their current operations and creating new strategies to keep up with competitors, especially for companies that have survived after the dot.com collapse (Wen, Lim, \& Huang, 2003). Hulland, Wade, and Antia (2007) examine the relationship between firms' commitment to online channels and online channel 
performance. The findings indicate that the online channel commitment plays a significant role in determining the online channel performance of firms.

Financial performance evaluation of Internet channels using traditional accounting measures may be inappropriate. Reflecting upon Copeland and Weston's (1983) opinion, accounting measures can only provide a limited reflection of true shareholder values generated by Internet channels investments. As suggested by Mandel (2000), more intangibles such as brand names and R\&D should be considered as evaluation indexes. Stock prices, a kind of economic measures which also reflect such intangibles, are therefore deemed by Milbourn (1996) the best financial performance measures. Accordingly, event study that incorporates abnormal return of stocks based on a particular event to the capital market into stock prices is considered a better means for performance evaluation. A pioneer work conducted by Geyskens et al. (2002) attempted to introduce event study to evaluate the performance of Internet channels. In this study, an attempt was therefore initiated to explore the relationship between Internet channels and a firm's market value by measuring its AR value using event study methodology. Nevertheless, its inherent nature of short term view of such a process/methodology (Jakobsen \& Voetmann, 2003) leads us to apply another "value-added" economic measures of firm performance, i.e., EVA, to capture its market assessment from a more long term perspective and to verify the result of event study methodology.

\section{Event Study}

Event study draws on the efficient market hypothesis that capital markets are efficient mechanisms to process information available on firms. (Fama, Fisher, Jensen, \& Roll, 1969). The logic underlying the hypothesis is the belief that investors will rapidly process publicly available information on firm activities and the extent to which they adjust their expectations of the market value of the firm based on such a specific event. Therefore, the strength of this method is its potential to associate the link between the firm's actions and its respective market values in terms of its stock prices (McWilliams \& Siegel, 1997). Due to its strength, event study has been well accepted and widely employed in a variety of disciplines (Agrawal \& Kamakura, 1995). Examples of the event study application on management include market expansion strategy (Mas, Nicolau, \& Ruiz, 2006), celebrity endorsements (Agrawal \& Kamakura, 1995), strategic alliances (Kalaignanam, Shankar, \& Varadarajan, 2007), IT investments (Meng \& Lee, 2007), electronic commerce announcement (Subramani \& Walden, 2001; Dewan \& Ren, 2007) and Internet channel additions (Geyskens et 
al., 2002). To elaborate, Lin, Jang, and Chen (2007) apply the event study methodology to assess the market value of e-service initiatives. Their results show that abnormal returns accompanying e-service announcement are positive.

\section{Economic Value Added}

EVA, classified to as "value-added" measure, was introduced in the 1980s (Reilly \& Brown, 1997). In recent years, the measure has received considerable attention in both business and academics as new indicators of a firm's valuation in a variety of fields, such as compensation systems (Baum, Sarver, \& Strickland, 2004), decision making (Bhalla, 2004; Reilly \& Brown, 1997) and incentive bonus plans (Riceman, Cahan, \& Lal, 2002). EVA is based on the concept that if a company's return on capital exceeds its cost of capital, it creates true value for shareholders (Chen \& Dodd, 1997). In general, EVA is defined as a measure of the value added to the business over a period of time. Therefore, EVA is computed as the Net-Operating-Profit-After-Tax (NOPAT) for a period of time minus the cost of the capital over that period. NOPAT is derived by adding back to reported net operating profit amounts that represent non-cash items, such as the increase in bad debt reserve, amortization of goodwill and the increase in capitalized R\&D costs. The cost of the capital is defined as the minimum rate of return required by shareholders. The calculation of EVA involves adjustments to Generally Accepted Accounting Principles (GAAP) to reduce the influence of management activities: such as operating leases payments, bad debt reserve and capitalized value of R\&D and advertising. The goal of such adjustments is to reflect the economic value of the firm instead of traditional accounting measures guided by GAAP. Traditional accounting measures understate the cost of the capital by ignoring the opportunity cost of the capital and such adjustments of the EVA measure can take this ignorance into account. Therefore, EVA is praised for its effectiveness in evaluating the true economic performance (Bhalla, 2004; Chen \& Dodd, 1997; Sandoval, 2001).

\section{HYPOTHESES DEVELOPMENT}

Recent research emphasizes the abilities to build and maintain relationships with client, due in part to the information and communication capabilities offered by the Internet (Gaustad, 2002). The Internet makes it possible for marketer to effectively interact with individual consumers (Pötzl, 2000). One significant benefit of Internet channels is based on the concept of virtual storefronts (Pitt, Berthon, \& Berthon, 1999), in which the coordination costs of reaching and selling to wide numbers of 
consumers are lower than those within the physical store context. Announcements of Internet channel additions are expected to exploit opportunities created by the growth of IT, thus creating benefits to the firm in the future (Subramani \& Walden, 2001). Further, adding Internet channels suggest that a firm is planning to take advantage of significant efficiencies in streamlining operational processes through the deployment of IT (Hamel \& Sampler, 1998). Consistent with the signaling hypothesis (Fama et al., 1969), announcements of Internet channels are the ways for firms to deliver favorable private information to investors such as the presence of an innovative, forward-looking, profit-oriented management team leveraging new technologies and acquiring organizational capabilities to address growing electronic markets (Madlberger \& Kotzab, 2001).

These arguments suggest that firms announcing Internet channels are likely to realize significant strategic and operational advantages in the future. If so, investors should react positively to Internet channels announcements, creating a positive abnormal return around the date of Internet channels announcement by firms. This leads to the hypothesis that Internet channels are associated with enhanced benefits streams in the future and consequently enhanced market valuation in terms of abnormal returns. We describe the hypothesis 1 below:

\section{$H_{1}$ : The abnormal returns attributable to Internet channels announcements are positive.}

In addition to its appropriateness in the context of Internet channels, EVA has some properties that a measure capturing true value of the firm should be depicted. This measure taps into the brand and intangible value of firms by making adjustments for R\&D expenditures and amortized goodwill (Stern \& Stewart, 1997). The properties of EVA support the appropriateness of its use in IT regarding to Internet channels. Adding an Internet channel can enhance true value of firms through demand-side advantages: market expansion, brand switching, and relationship deepening; supply-side advantages: lower physical distribution costs, and lower transaction costs (Geyskens et al., 2002). According to O'Byrne (1996) argued that EVA explains significantly more of the variation in stock returns than the level of earnings, and EVA is significantly positive related to abnormal returns in the name of market valuation (Sandoval, 2001). For that reason, the study describes the hypothesis 2 and hypothesis 3 below: 
$\mathrm{H}_{2}$ : The relationship between Economic Value Added before/after adding Internet channels and Abnormal Returns is positive.

$\mathrm{H}_{3}$ : Economic Value Added after adding Internet channels dominates Economic Value Added before adding Internet channels in explaining Abnormal Returns.

\section{RESEARCH METHODOLOGY}

\section{Sample and Data Collection}

The target population was defined as Taiwan physical enterprises which introduced eCommerce into their business operation and allowed customers to purchase goods both through their physical and Internet channels. eCommerce here is communicated as order placing through the Internet. Physical financial service firms providing order services through the Internet were chosen as representatives of it. The decision of involving in a single industry, financial services, was mainly based on the rationale of reduction of variances across industries. Besides, this industry provided enough number of firms which had introduced Internet channels and were listed on the Taiwan Stock Exchange market where their stock prices could be collected for subsequent research analysis purpose. During the last few years, according to Taiwan Institute of Economic Research, Taiwan has experienced a wave of introducing Internet channels in financial service sector. This has been driven by the survival reason to offer better services to enhance customer loyalty after Taiwan's authority deregulated financial service sector in November of 1997.

From a list of firms provided by Taiwan Stock Exchange Corporate, thirty-two Taiwanese financial service firms were identified to be qualified. These firms announced their Internet channel additions over the period 1997-2003. Their financial data were then collected from the TEJ database. TEJ, provided by Taiwan Economic Journal Co., is the most important and largest financial database in Taiwan, where Taiwan firms' financial statements, reports, etc. can be tracked.

\section{Data Analysis Methods}

Event study methodology and general least squared regressions (GLS regressions) were used to assess the effect of Internet channels on the market value in this study. Following Subramani and Walden's (2001) event study analysis process, the event was defined as a public announcement of introducing Internet channels on the media in the beginning for firms. We used daily stock returns and an estimation period of 240 days for the calculation of the CARs over one event windows: ten days before and ten days after the event. The length of the estimation period and the event windows used were 
consistent with prior studies of capital market responses (Agrawal \& Kamakura, 1995). The financial data were obtained from the TEJ database to calculate the AR and EVA as variables.

\section{RESULTS}

\section{Effect of Internet Channels on AR}

The AARs and CAARs observed for the thirty-two announcements in the sample and the test for significance of the effect are presented in table 1. Results show that, on average, announcements of Internet channels are associated with positive abnormal returns. The AARs for the event date is $0.63 \%$, which is statistically significant $(\mathrm{t}=3.363, \mathrm{p}<0.01)$. Furthermore, firms establishing an Internet channel experienced $1.16 \%$ CAARs on the event date and $1.58 \%$ CAARs on the next date. Of all windows surrounding the event day, one from 0 to +1 shows the most significant CAAR, with a value of $2.74 \%$.

Table 1 AARs and CAARs for Internet Channels

\begin{tabular}{|c|c|c|c|}
\hline Event Day & AARs (\%) & t-value & CAARs $(\%)$ \\
\hline-10 & -0.26 & -1.01 & -0.26 \\
\hline-9 & 0.22 & 1.404 & -0.04 \\
\hline-8 & -0.13 & -0.444 & -0.17 \\
\hline-7 & -0.11 & -0.194 & -0.28 \\
\hline-6 & 0.49 & $2.043^{*}$ & 0.21 \\
\hline-5 & -0.33 & -1.926 & -0.12 \\
\hline-4 & 0.08 & 0.671 & -0.04 \\
\hline-3 & -0.06 & -0.372 & -0.10 \\
\hline-2 & 0.53 & $2.117^{*}$ & 0.43 \\
\hline-1 & 0.10 & 0.354 & 0.53 \\
\hline 0 & 0.63 & $3.363^{* *}$ & 1.16 \\
\hline+1 & 0.42 & $2.205^{*}$ & 1.58 \\
\hline+2 & -0.19 & -0.333 & 1.39 \\
\hline+3 & -0.30 & -1.14 & 1.09 \\
\hline+4 & -0.51 & $-2.204^{*}$ & 0.58 \\
\hline+5 & -0.16 & -1.126 & 0.42 \\
\hline+6 & 0.08 & 0.705 & 0.50 \\
\hline+7 & 0.16 & 0.596 & 0.66 \\
\hline+8 & -0.27 & -1.218 & 0.39 \\
\hline+9 & -0.13 & -0.325 & 0.26 \\
\hline+10 & 0.03 & 0.267 & 0.29 \\
\hline
\end{tabular}

Note: The t-value reported is for the 2-tailed test; ${ }^{*} \mathrm{p}<0.05,{ }^{* *} \mathrm{p}<0.01,{ }^{* * *} \mathrm{p}<0.001$ 
To illustrate the results graphically, the bars in the graph on figure 1 and figure 2 represent the AARs as well as CAARs on each of the 21 days surrounding announcement date in the $[-10,+10]$ windows. Our short event window $[0,+1]$ implies an instantaneous adjustment in stock prices to the information of Internet channels. This pattern on the size of stock market reaction to Internet channels is consistent with AARs and CAARs reported in other marketing-related event studies (Agrawal \& Kamakura, 1995; Cheng, Tsao, Tsai, \& Tu, 2007). The magnitudes of the AARs and CAARs are uniformly positive and significant in $[-10,+10]$ windows and thus provide strong support for $\mathrm{H}_{1}$.

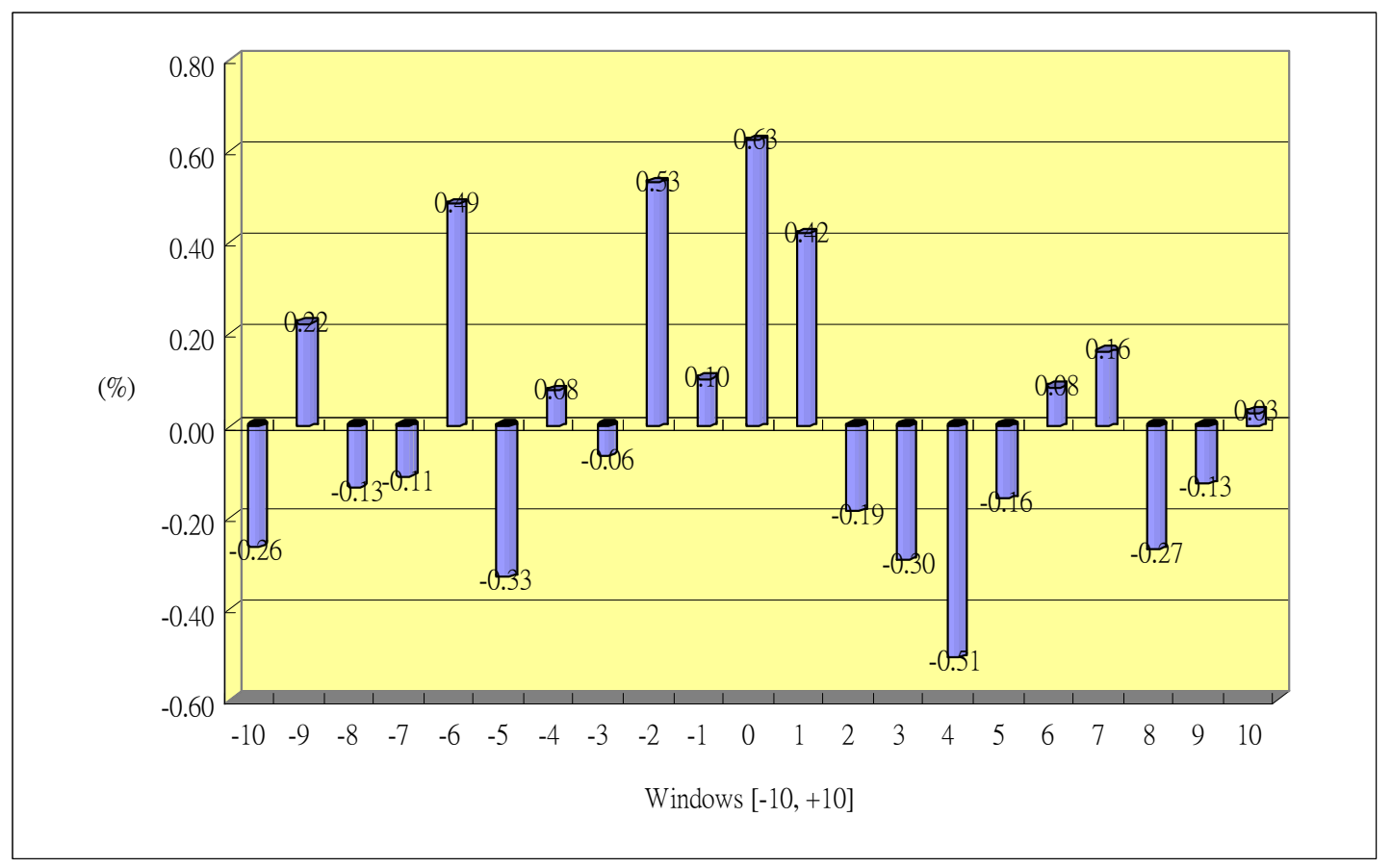

Figure 1 Average Abnormal Returns for All Firms

\section{Effect of Internet Channels on EVA}

Regression analysis was employed to assess the performance of Internet channels. The results indicate that EVA before adding Internet channels is positively related to AR at the 5\% level (see Table 2) while the relationship between EVA after adding Internet channels and $\mathrm{AR}$ is positive at the $0.1 \%$ level (see Table 3 ). To be more explicit, one percent increase in EVA before Internet channels additions results in a 0.112 percent increase in AR, and one percent increase in EVA after Internet channels additions leads to a 0.297 percent increase in AR. Moreover, we use Adjusted $\mathrm{R}$-squared as a test of association (goodness of fit). The evidence shows that the Adjusted- $\mathrm{R}^{2}$ of EVA after adding Internet channels (Adjusted- $\mathrm{R}^{2}=8.6 \%$ ) outperforms 
EVA before adding Internet channels (Adjusted- $\mathrm{R}^{2}=0.9 \%$ ); that is, EVA after adding Internet channels would explain better than EVA before adding Internet channels the presence of AR for firms. In summary, an increase in EVA leads to an increase in AR which provides strong support for $\mathrm{H}_{2}$ and $\mathrm{H}_{3}$.

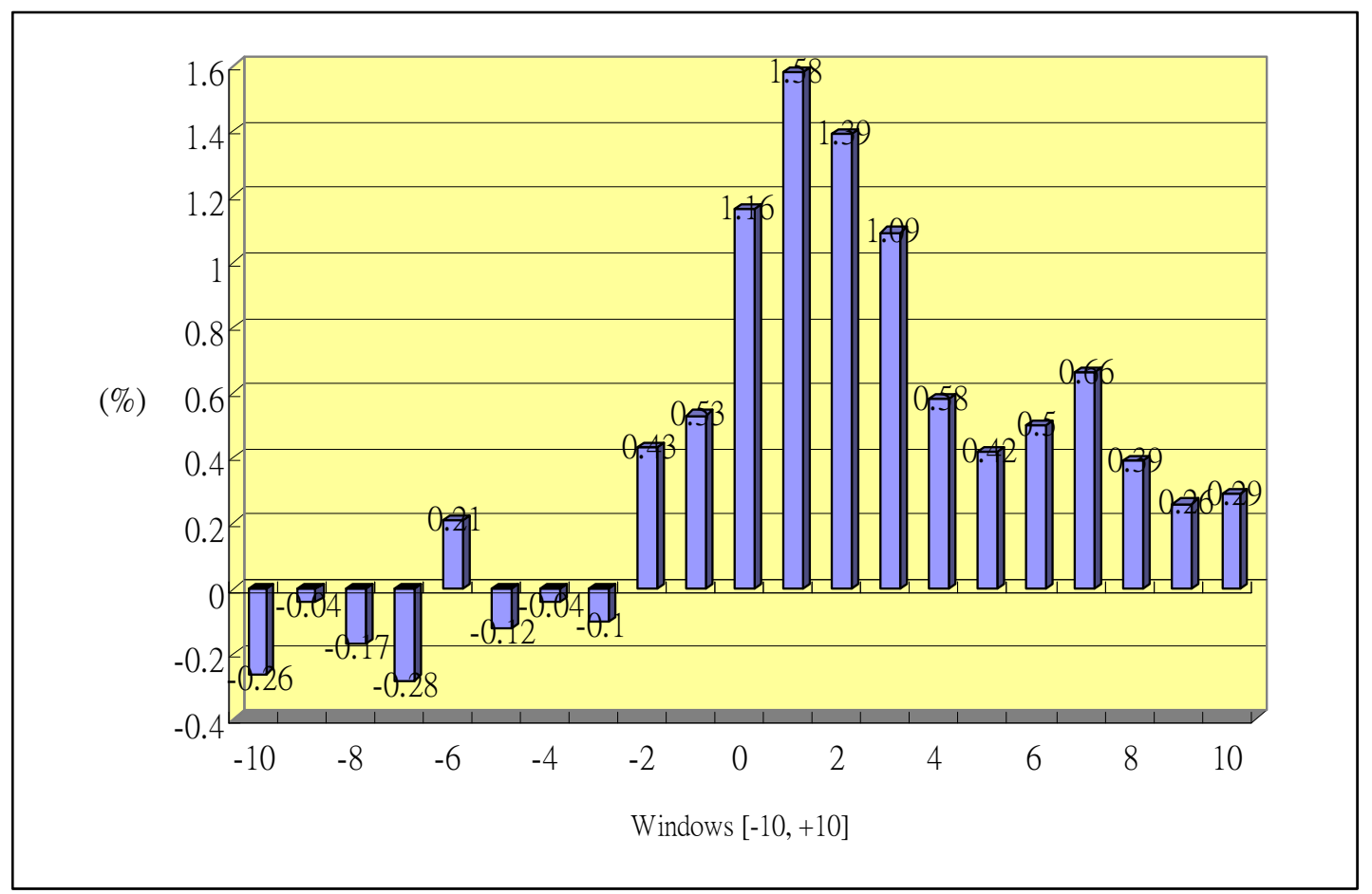

Figure 2 Cumulative Average Abnormal Returns for All Firms

Table 2 AR as Explained by the EVA before Internet Channels

\begin{tabular}{cccc}
\hline Variable & Coefficient & t-value & Adjusted-R $^{2}$ \\
\hline Intercept $(\alpha)$ & 0.0223 & 0.453 & 0.009 \\
\hline $\operatorname{Beta}\left(\mathrm{EVA}_{\mathrm{b}}\right)$ & 0.112 & $2.036^{*}$ & \\
\hline
\end{tabular}

Table 3 AR as Explained by the EVA after Internet Channels

\begin{tabular}{cccc}
\hline Variable & Coefficient & t-value & Adjusted- ${ }^{2}$ \\
\hline Intercept $(\alpha)$ & 0.0304 & $5.951^{* * *}$ & 0.086 \\
\hline Beta $\left(\mathrm{EVA}_{\mathrm{a}}\right)$ & 0.297 & $5.587^{* * *}$ & \\
\hline
\end{tabular}

Note: The dependent variable is abnormal returns.

$\mathrm{EVA}_{\mathrm{a}}$ refers to the EVA after Internet channels.

$\mathrm{EVA}_{\mathrm{b}}$ refers to the EVA before Internet channels.

${ }^{*} \mathrm{p}<0.05,{ }^{* *} \mathrm{p}<0.01,{ }^{* * *} \mathrm{p}<0.001$ 
Overall, our results are:

a. Capital markets react positively to the announcements of Internet channels, leading to a significant enhancement of the firm's market value. The AARs for the event date is $0.63 \%$, which is statistically significant $(\mathrm{t}=3.363, \mathrm{p}<0.01)$.

b. The relationship between EVA before/after adding Internet channels and AR is positive; in addition, EVA after adding Internet channels dominates EVA before adding Internet channels in explaining AR.

\section{CONCLUSIONS}

The valuation of Internet channels has received considerable attention in marketing literature. To address the important issue, an attempt was made to fill in the literature gap from two performance measures: AR and EVA. By using event study methodology, it was shown that positive and significant ARs were found around the dates when introducing Internet channels were announced. Capital markets reacted positively to the announcements of Internet channels, leading to a significant enhancement of the firm's market value. As has been noted previously however, there may be problems in looking upon this phenomenon due to the inherent short term view of event study methodology. In order to clear up this thorny drawback, this research adopted another "value-added" measure, EVA, to assess the performance of the firm after introducing Internet channels in a more long term perspective. The findings of the present research also provided empirical support that EVA after adding Internet channels was significantly different from this before adding Internet channels. All these results suggest that Internet channels have a direct and positive influence on the performance of firms after the emergence of the Internet. In conclusion, the research has provided insights into the performance implications of Internet channels for firms.

\section{Managerial Implications and Future Research}

This research sheds light on two important implications. First, this study provides evidences for Internet channels on the market value. Adding an Internet channel to a firm's channel portfolio has the merits and demerits. However, managers facing the emergence of the Internet feel pressured to decide how to best respond to this marketplaces now. Managers could use our research to identify the performance of Internet channels. The finding concludes that the announcements of Internet channels are associated with significant increases in market valuation of firms, no matter from the viewpoints of AR and EVA measures. This effect allows managers to make wiser 
decisions to get involved in eCommerce. Therefore, it is important for managers to understand the content of eCommerce and invest in this changeable virtual Internet environment. Based on our research, we can suggest the following developments on the Internet channels for firms.

1. Firms will continue to invest in their own Internet channels and offer direct links to selected customers in the future. The design and management of Internet channels are powerful weapons in an increasingly competitive business environment.

2. As the distribution channel management becomes increasingly elaborated, firms will gain experience in effectively managing price, profitability, brand, and display positioning in many distribution channels and avoid channel conflict.

3. Firms that added an Internet channel should provide other value-added services through Internet, for example, timely delivery and special offers.

This research represents an inquiry into a complex phenomenon. As such, the study has several limitations that offer immediate avenues for further research. The first limitation may be the use of secondary data. An attractive feature of secondary data in our case is the possibility of gaining access to the past, which may be subject to problems of recall or worse, lead to potential construct validity problems. In order to overcome this, further research should employ primary data to investigate the current issue. The second limitation is that only one industry in Taiwan is included in this research. As potential idiosyncratic industry- and country-related properties of our data is believed to occur, the generaliability of the results needs to be assessed. Therefore, future studies involving other industries and countries might also provide worthwhile insights. Third, firms' performances are rather a complex phenomenon which requires more than a single criterion to characterize it (e.g., King \& Liou, 2004; Wen et al., 2003). Therefore, the research suggests better applying multi-factor performance measurement models, such as Balanced Scorecard (BSC) approach, to address the current theme.

\section{Acknowledgements}

This research project was sponsored by the Taiwan National Science Council (NSC 98-2410-H-126-004-) and supported in part by the School of Management, Providence University. 


\section{REFERENCES}

Agrawal, J., \& Kamakura, W. A. (1995). The economic worth of celebrity endorsers: An event study analysis. Journal of Marketing, 59(3), 56-62.

Aitchison, P., \& Stone, M. (2002). The impact of e-commerce on UK financial services product providers and their intermediary relationships. Pensions: An International Journal, 8(1), 63-78.

Baum, C. L., Sarver, L., \& Strickland T. (2004). EVA, MVA and CEO compensation: Further evidence. American Business Review, 22(2), 82-87.

Bhalla, V. K. (2004). Creating wealth: corporate financial strategy and decision making. Journal of Management Research, 4(1), 13-34.

Chen, S., \& Dodd, J. L. (1997). EVA: An empirical examination of a new corporate performance measure. Journal of Managerial Issue, 9(3), 318-333.

Cheng, J. M-S., Tsao, S-M., Tsai, W-H., \& Tu, H. H-J. (2007). Will eChannel additions increase the financial performance of the firm? The evidence from Taiwan. Industrial Marketing Management, 36(1), 50-57.

Copeland, T. E., \& Weston, J. E. (1983). Financial theory and corporate policy. Reading, MA: Addison-Wesley.

Dewan, S., \& Ren, F. (2007). Risk and return of information technology initiatives: Evidence from electronic commerce announcements. Information Systems Research, 18(4), 370-394.

Fama, E. L., Fisher, L., Jensen, M. C., \& Roll, R. (1969). The adjustment of stock prices to new information. International Economic Review, 10(1), 1-21.

Frazier, G. L., Gill, J. D., \& Kale, S. H. (1989). Dealer dependence levels and reciprocal actions in a channel of distribution in a developing country. Journal of Marketing, 53(1), 50-69.

Gaustad, T. (2002). The rroblem of excludability for media and entertainment products in new electronic market channels. Electronic Markets, 12(4), 248-251.

Geyskens, I., \& Steenkamp, J-B. E. M. (2000). Economic and social satisfaction: Measurement and relevance to marketing channel relationships. Journal of Retailing, 76(1), 11-32.

Geyskens, I., Gielens, K., \& Dekimpe, M. G. (2002). The marketing valuation of internet channel addition. Journal of Marketing, 66(2), 102-119.

Hamel, G., \& Sampler J. (1998). The e-corporation: More than just web-based, it's building a new industrial order. Fortune, 138(11), 80-92. 
Hulland, J., Wade, M. R., \& Antia, K. D. (2007). The impact of capabilities and prior investments on online channel commitment and performance. Journal of Management Information Systems, 23(4), 109-142.

Jakobsen, J., \& Voetmann, T. (2003). Post-acquisition performance in the short and long run. Evidence from the Copenhagen Stock Exchange 1993-1997. European Journal of Finance, 9(4), 323-342.

Kalaignanam, K., Shankar, V., \& Varadarajan, R. (2007). Asymmetric new product development alliances: Win-win or win-lose partnerships? Management Science, 53(3), 357-374.

Katsikeas, C. S., Paparoidamis, N. G., \& Katsikea, E. (2004). Supply source selection criteria: The impact of supplier performance on distributor performance. Industrial Marketing Management, 33(8), 755-764.

King, S. F., \& Liou, J-S. (2004). A framework for internet channel evaluation. International Journal of Information Management, 24(6), 473-488.

Kumar, N., Stern, L. W., \& Achrol, R. S. (1992). Assessing reseller performance from the perspective of the supplier. Journal of Marketing Research, 29(2), 238-253.

Lin, J. S., Jang, W. Y., \& Chen, K. J. (2007). Assessing the market valuation of e-service initiatives. International Journal of Service Industry Management, 18(3), 224-245.

Madlberger, M., \& Kotzab, H. (2001). Adapting the Internet as distribution channel for stationary retailers: The Austrian case. Electronic Markets, 11(1), 64-74.

Mandel, M. J. (2000). The coming Internet depression: Why the high-tech boom will go bust. Business Week, October 9, 72-180.

Mas, F., Nicolau, J., \& Ruiz, F. (2006). Foreign diversification vs concentration strategies and firm performance. International Marketing Review, 23(1), 54-82.

McWilliams, A., \& Siegel, D. (1997). Event studies in management research: Theoretical and empirical issues. Academy of Management Journal, 40(3), 626-657.

Meng, Z., \& Lee, S.-Y. T. (2007). The value of IT to firms in a developing country in the catch-up process: An empirical comparison of China and the United States. Decision Support Systems, 43(3), 737-745.

Milbourn, T. (1996). The executive compensation puzzle: Theory and evidence. IFA Working Paper No. 235, London Business School.

O'Byrne, S. F. (1996). EVA and market value. Journal of Applied Corporate Finance, 9(1), 116-125. 
Pitt, L., Berthon, P., \& Berthon, J-P. (1999). Changing channels: The impact of the Internet on distribution strategy. Business Horizons, 42(2), 19-28.

Pötzl, J. (2000). Issues in direct channel distribution: A comparison of selling via the Internet in the airline business and the fast-moving consumer goods industry. Electronic Markets, 10(3), 153-157.

Rajkumar, V., \& Kumar, V. (2004). A customer lifetime value framework for customer selection and resource allocation strategy. Journal of Marketing, 68(4), 106-125.

Ramaseshan, B., Yip, L. S. C., \& Pae, J. H. (2006). Power, satisfaction, and relationship commitment in Chinese store-tenant relationship and their impact on performance. Journal of Retailing, 82(1), 63-70.

Reda, S. (1999). Internet channel conflicts. Stores, 81(12), 24-28.

Reilly, F. K., \& Brown, K. C. (1997). Investment analysis and portfolio management (5th ed.). Fort Worth: The Dryden Press.

Riceman, S., Cahan, S., \& Lal, M. (2002). Do managers perform better under EVA bonus schemes? European Accounting Review, 11(3), 537-572.

Sandoval, E. (2001). Financial performance measures and shareholder value creation: An empirical study for Chilean companies. Journal of Applied Business Research, 17(3), 109-122.

Sharma, D., Sahay, B. S., \& Sachan, A. (2004). Modelling distributor performance index using system dynamics approach. Asia Pacific Journal of Marketing and Logistics, 16(3), 37-67.

Spriggs, M. T. (1994). A framework for more valid measures of channel member performance. Journal of Retailing, 70(4), 327-343.

Stern, J., \& Stewart, G. B. (1997). The EVA company. New York: Stern \& Stewart Co. Publications.

Stewart, D. W., \& Zhao, Q. (2000). Internet marketing, business models, and public policy. Journal of Public Policy \& Marketing, 19(2), 287-296.

Subramani, M., \& Walden, E. (2001). The impact of e-commerce announcements on the market value of firms. Information Systems Research, 12(2), 135-154.

Wen, H. J., Lim, B., \& Huang, H. L. (2003). Measuring e-commerce efficiency: A data envelopment analysis (DEA) approach. Industrial Management \& Data Systems, 103(9), 703-710.

Zettelmeyer, F. (2000). Expanding to the Internet: Pricing and communications strategies when firms compete on multiple channels. Journal of Marketing Research, 37(3), 292-308. 
